Fund is in the sole discretion of the Committee of Award, which will conduct interviews at Harkness House, London, in March 1965. Further information and details of the fellowships can be obtained from the Warden, Harkness House, 38 Upper Brook Street, London, W.1. Applications, on forms provided by the Fund, must reach Harkness House before November 12.

\section{The Paul Instrument Fund Award}

THE Paul Instrument Fund Committee has made grants as follows: $£ 1,100$ to Dr. P. B. Hirsch, lecturer in physics in the University of Cambridge, as a supplementary grant, for continuation of his work on an electron microscope with velocity analyser. $£ 5,400$ to Prof. D. J. E. Ingram, professor of physics, University of Keele, for the design and construction of a millimetre wave-length electron resonance spectrometor to work at zero or near zero magnetic field strengths and with as wide a frequency coverage as possible. $£ 2,200$ per annum for two years to Dr. H. Motz, Donald Pollock reader in engineering, University of Oxford, for the construction of a pulsed millimetre wave generator. $£ 3,400$ to Dr. E. E. Schneider, reader in solid-state physics, University of Newcastle upon Tyne, as a supplementary grant, for continuation of his work on the application of superconducting cavities to magnetic resonance spectrometers. The Paul Instrument Fund Committee, composed of representatives of the Royal Society, the Institute of Physics and the Physical Society and the Institution of Electrical Engineers, was set up in 1945 "to receive applications from British subjects who aro research workers in Great Britain for grants for the design, construction and maintenance of novel, unusual or much improved types of physical instruments and apparatus for investigations in pure or applied physical science".

\section{The Australian Association of Clinical Biochemists}

THe following have been elected officers of the Australian Association of Clinical Biochemists for the year 1964-65: President, Dr. W. Roman; Secretary, Dr. D. H. Curnow; Treasurer, Dr. D. Watson; State Representatives on Council, Mr. M. J. Thomas (Queensland); Dr. F. J. Radeliff (New South Wales); Dr. J. Mackenzie (Victoria); Mr. Z. A. Mojglo (Tasmania); Dr. R. I. Cox (South Australia); and Dr. S. S. Alexander (West Australia).

\section{Institute of Applied Science of Victoria}

THe annual roport for $1962-63$ of the Institute of Applied Science of Victoria records that the new name, "Institute of Applied Science", bestowed by an Act of Parliament in 1961, may now be seen across the outside entablature of the building (Pp. 22. Melbourne: Instituto of Applied Science of Victoria, 1964). The post-war years have witnessed the metamorphosis of the original Industrial and Technological Muscum into an establishment which now includes a planetarium, a radiocarbon-dating laboratory, evening astronomical telescope demonstrations, special school services, and a fresh approach to applied science display. A large diorama illustrates the Yallourn open-cut works for coal and shows the overburden stratum and various working levels. The model also includes a 1,200-ton coal-winning dredge, belt conveyor, water-spray reticulation, etc. Another display given by Qantas Empire Airways deals with aeroplane engines and summarizes progress from the Wright brothers to turbo-props and turbo-jet propulsion.

\section{University News:}

London

Dr. E. A. Bevan, University lecturer and demonstrator in the University of Oxford, has been appointed to tho chair of botany at Queen Mary College. Dr. James Green, lecturer at Bedford College, has been appointed to the readership in zoology at Westfield Colloge. The following titles have been conferred: professor of sociology (with special reference to the Far East), on Mr. R. P. Dore in respect of his post at the London School of Economics and Political Science and the School of Oriental and African Studies; professor of plant chemistry, on Dr. L. Fowden in respect of his post at University College; professor of geography, on Dr. R. J. Harrison-Church in respect of his post at the London School of Economics and Political Science; reader in geography, on Dr. K. M. Clayton in respect of his post at the London School of Economics and Political Science, and on Dr. J. T. Coppock in respect of his post at University College; reader in chemistry, on Dr. A. G. Davies in respect of his post at University College; reader in forensic psychiatry, on Dr. T. C. N. Gibbens in respect of his post at the Institute of Psychiatry; reader in comparative education, on Dr. B. Holmes in respect of his post at the Institute of Education.

\section{Announcements}

THE autumn meeting of the Society for Water Treatment and Examination will be held at Llandudno during September 30-October 2. Further information can be obtained from A. W. H. McCanlis, 41 Carshalton Road, Sutton, Surrey.

A symposium on "Major Elements in Nutrition", organized by the Scottish Group of the Nutrition Society, will be held in Dundee on September 12. Further information can be obtained from Dr. C. F. Mills, Rowett Research Institute, Bucksburn, Aberdeen.

A meeting of the Biochemical Society will be held in the University of Cambridge during Septembor 17-18. Further information can be obtained from Dr. H. R. V. Arnstein, National Institute for Medical Research, The Ridgeway, Mill Hill, London, N.W.7.

A symposium on "The Problems of Food Additives", organized by the Royal Institute of Chemistry, will be held in Manchester on October 1. Further information can be obtained from H. H. Armstrong, Stockport College for Further Education, Wellington Road South, Stockport.

A sUMmer school in "Organic Spectroscopy", arranged by the Royal Institute of Chemistry in collaboration with the Society for Analytical Chemistry, will be held in the University of London School of Pharmacy during September 6-12. Further information can be obtained from D. G. Chisman, Royal Institute of Chemistry, 30 Russell Square, London, W.C.1.

The fifth international Machine Tool Design and Research Conference will be held in the University of Birmingham during September 14-18. Tho Conference will include sessions on: international collaboration on machine tool chatter research sponsored by the U.S. Air Force; machine tool design; high-energy rate forming; metal cutting; explosive forming; metal forming; recent developments in machine tool technology. Further information can be obtained from the Organizing Secretary, Department of Mechanical Engineering, University of Birmingham, Edgbaston, Birmingham 15.

THE eighth Conference on Analytical Chemistry in Nuclear Technology on "The Determination of Interstitials and Trace Constituents in Reactor Materials and Products", sponsored by the Analytical Chemistry Division of Oak Ridge National Laboratory, will be held in Gatlinburg, Tennessee, during October 6-8. The Conference will include sessions on: spectrochemical and $\mathrm{X}$-ray methods of analysis; mass spectrometric methods of analysis; nuclear methods of analysis; gas chromatographic methods of analysis; determination of carbon, hydrogen, oxygen and nitrogen in metals; determination of trace constituents by diverse methods. Further information can be obtained from C. D. Susano, Oak Ridge National Laboratory, P.O. Box X, Oak Ridge, Tennessee, 37831 . 